\title{
The Performance of Turkish Manufacturing Firms in Stable And Unstable Economic Periods
}

\section{Nizamettin Bayyurt}

\begin{abstract}
Generally, profitability is used to evaluate the performance of companies. Yet performance is a multidimensional concept, and therefore a single indicator is incapable of adequately defining its various aspects and providing a clear perspective on the critical mission of organizations. The measurement of the performance of a company is the evaluation of the level of attainment of the company's aims. Many factors can affect such aims. Companies must determine their own critical performance indicators and discover the relations between these indicators for optimal management and progress. The aim of this study is to discuss these business performance indicators, the relations between performance indicators and the factors that affect these indicators in the Turkish manufacturing industry, and to discuss how these relations vary during economically stable and unstable periods.
\end{abstract}

Key words: Performance Measurement, Canonical Correlation, Turkish Manufacturing Industry

JEL : L21, L25, L20

\section{Business Performance and Perfor- mance Indicators}

Various definitions of performance exist in business literature. Amaratunga, et al., (2000) defines performance for an organization as the manner or quality of its functioning. According to Akal (1996), performance is a concept that describes the qualitative or quantitative results of activities. Chin, et al., [2003] measures performance by the evaluation of the efficiency and productivity of the organization, while Neely et al., (1995) describe performance measurement as a process of quantifying the efficiency and effectiveness of action that leads to performance. Performance can be defined as the ability to achieve a task, or evaluation of the level of the attainment of the organization's aims.

An organization's aims depend on whether it is in the public or private sector. The benefits of the public are not considered as much by private organizations as public ones. Increased prices, layoffs, and lower wages in privatized companies are evidence of this (La Porta, De-Silanes, 1999).

Different performance criteria have been used in literature,

\section{DOI: $10.2478 / \mathrm{v} 10033-007-0004-2$}

including effectiveness, efficiency and rate of utilization, productivity, quality of work life, profitability, quality and innovation. Since these variables are independent of one other, managers should decide which ones to consider in measuring business performance with respect to the goals and priorities of the firm (Akal, 1994)

A company is an economic enterprise and its basic goal, with the exception of charitable corporations, is to maxi-

\footnotetext{
*Nizamettin Bayyurt

Fatih University, Faculty of Economic

and Administrative Sciences,

Department of Management

34500 Buyukcekmece, Istanbul, Turkey

Tel: + 902128890810

Fax: + 902128890832

E-mail: bayyurt@fatih.edu.tr
} 
mize profit. Kald and Nilson (2000) indicated that performance is a means of profitability. But the maximization of profitability cannot be the only goal of companies, because that can be achieved by selling shares or investing in bonds while earnings per share decrease. Maximization of earning per share is another aim of a company. Yet earning per share does not consider the risk, period, and timing of the expected income. The maximization of market value of a company for shareholders is another aim (Brigham, Ehrhardt, 2002). While growth can also be viewed an aim, many companies once prone to growth have gone bankrupt. Productivity is one of the most important aspects of the economic life of a society. It is crucial for the survival and prosperity of firms. Therefore, productivity is one of the main goals of companies. Kaplan and Norton recognize that a single measure of performance cannot offer a comprehensive perspective of the critical mission of an organization (Kaplan, Norton, 1996). As a result, business performance must be evaluated with multidimensional perspectives. In this study, the four measures of profitability, productivity, stock returns and growth are used to evaluate the business performance of the Turkish manufacturing industry.

The performance of the firms were affected by many factors, such as the financial structure of the organization, management style, quality, innovation, research and developments (Shaker, Covin, 1993 and 1995), debts (Toy et. al., 1974), (Opler and Titman, 1994), cash flow (Salmi et. al., 1997), firm size (Günçavdı et. al., 1999), environmental situations like dynamism, complexity, hostility (Luo, Park, 2001), and some unobservable factors like corporate culture, access to scarce resources, management skill and luck (Jacobson, 1990).

In this study, the relations between performance and predictor variables in the Turkish manufacturing industry during both economically stable and unstable times were investigated and compared by multivariate statistical analyses.

\section{The Method}

Canonical correlation was used for the analysis. It seeks to identify and quantify the associations between two sets of variables (Johnson, Wichern, 2002). It is the most general method that can be used for both the metric and nonmetric values of the sets $Y$ (dependent, criterion) and $X$ (independent, predictor) (Hair et al., 1998). While canonical correlation is used for explaning the relation between dependent and independent variables, it explains not only which independent variable has an effect on which dependent variable, but also which independent variable has a greater effect on specific dependent variables (Levine, 1977). It is similar to multiple regression analysis, except that there are several variables on both sides of the equation, optimally weighted and combined in a linear fashion to produce the highest correlation between the linear composites of the two-variable sets. The formulation is as follows. $u=a^{\prime} x$ and $v=\gamma^{\prime} y$ are the linear composites of the sets of the variables, where $a$ and $y$ are the coefficients similar to the coefficients of linear regression.

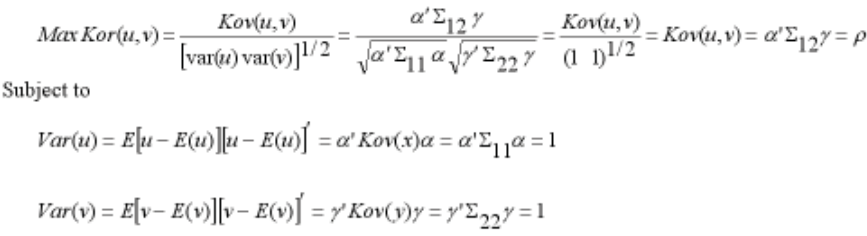

The optima of the function are found by means of Lagrange Multipliers $\lambda_{1}$ and $\lambda_{2}$. The Lagrange function $L$ and its optima are written as follows;

$$
\begin{aligned}
& L=\alpha^{\prime} \Sigma_{12} \gamma-\frac{1}{2} \lambda_{1}\left(\alpha^{\prime} \Sigma_{11} \alpha-1\right)-\frac{1}{2} \lambda_{2}\left(\gamma^{\prime} \Sigma_{22} \gamma-1\right) \\
& \frac{\partial L}{\partial \alpha}=\Sigma_{12} \gamma-\lambda_{1} \Sigma_{11} \alpha=0 \\
& \frac{\partial L}{\partial \gamma}=\Sigma_{21} \alpha-\lambda_{2} \Sigma_{22} \gamma=0
\end{aligned}
$$

The solution of these partial differentials results in an eigenvalue problem. The solution of that problem gives $p^{2}$. The vectors $a$ and $\gamma$ can be obtained from the equations by substituting $p^{2}$. These vectors are called canonical coefficients and maximize the linear combinations of the variables.

\section{The Research}

The firms included in this research were chosen from the Istanbul Stock Exchange's (ISE) list of traded companies in 1996-1997 and 2001-2002. These firms are also among Turkey's top 1000 major manufacturing companies. Data was collected from the journals of the Istanbul Chamber of Industry $(\mathrm{ICl})$ and the Year Books of Companies of the ISE. The research consisted of two parts. In the first, 120 manufacturing firms were randomly selected from the top 1000 manufacturing firms in the industry. 17 firms were taken out as outliers using a $5 \%$ level of significance by a test of Mahalanobis Distance. Canonical correlation was applied to the sample size of 103 firms in 1997, an economically 
stable period in Turkey. In the second part, canonical correlation analysis was applied to the data of the same firms with the same variables for the year 2002, during which Turkey was economically unstable. The sample size was 68 for the second part, as some of the firms included in the first analysis, due to the economic crises of November 2000 and February 2001, had either gone bankrupt or been removed from the list issued by the ICl of Turkey's top 1000 major manufacturing companies. Finally the results were compared. When the first analysis was applied to the sample of 68 firms used in the second part, there was no change in the results of the analysis. Therefore, the sample size had not been narrowed.

\section{Study Variables}

The business performance of Turkish manufacturing companies was measured by profitability (net profit margin), productivity (gross value added per employee), growth (value added growth rates), and stock returns (market value / book value; mv/bv). Value added growth rates for both terms were deflated by the inflation rates given by the State Institute of Statistics of Turkey in 1997 and 2002. Predictor (independent) variables that were thought to affect business performance used in this research included current ratio (total current assets / total current liabilities), leverage (total liabilities / total assets), cash flow ratio (profit before tax + depreciation + expenses not requiring cash outflow / short term debt + long term debt), firm size, machinery plant \& equipment per employee (mac \& eqp), inventories turnover, and research and development (R\&D).

Assets, shareholders equity, value added or sales can be used to measure firm size. Spearman rank correlations show high correlations between the ranks of the firms according to these four variables $(p<1 \times 10-4)$ for both of the terms. This shows that any one of these four variables can be used for firm size. In this research, the average of the ranks of the firms was used to reflect the effects of all the variables. The largest 48 firms were represented by 1 and the remaining 55 firms by 0 in 1997. In the second term, 30 firms were represented by 0 and the 38 firms left by 1 . Similarly, dummy variables were used for the firms that either have or lack R\&D investments, respectively. Machinery plant \& equipment per employee was used to measure the level of technology and industrialization of the firms.

\section{Results of Analysis}

For the analysis the SAS System for the Windows V8 statistical package was used. Table 1 displays the means and standard deviations of the variables for both of the years. Two economical crises took place in Turkey, one in November 2000 and the other in February 2001. Many small and large firms were affected by these crises. Interest rates inceased rapidly, production capacity rates decreased, bankruptcies were seen in many areas and unemployement increased. With the acceptance of a fluctuating currency rate in February 2001, firms that were already in debt extremly were driven into it further because of the rise in foreign currency, leading to many difficulties with solvency. Consequently, the year 2002 was economically unstable. When the two years are compared, it can be seen from Table 1 that growth and profitability were negative in 2002. Even though all the positive measures for firms decreased in 2002, leverages which are the debt indicator of firms increased.

\begin{tabular}{|c|c|c|c|c|}
\hline \multirow[b]{2}{*}{ Variables } & \multicolumn{2}{|c|}{1997} & \multicolumn{2}{|c|}{2002} \\
\hline & Mean & St.Dev & Mean & St.Dev \\
\hline Growth (\%) & 7,28 & 33,11 & $-20,62$ & 151,43 \\
\hline Profitability (\%) & 9,41 & 8,10 & $-12,89$ & 83,40 \\
\hline Productivity $\left(10^{12} \mathrm{TL}\right)$ & 6,07 & 5,49 & 0,05 & 0,041 \\
\hline MV/BV & 5,36 & 3,50 & 3,60 & 8,40 \\
\hline Current Ratio & 1,79 & 0,69 & 1,61 & 0,84 \\
\hline Inventory Turn. & 7,28 & 8,44 & 5,93 & 3,39 \\
\hline Cash Flow (\%) & 40,83 & 43,38 & 29,74 & 32,82 \\
\hline Size & 0,47 & 0,50 & 0,52 & 0,50 \\
\hline Mac\&Eqp $\quad\left(10^{9} \mathrm{TL}\right)$ & 6,60 & 6,31 & 5,98 & 8,63 \\
\hline Leverage (\%) & 53,74 & 17,61 & 76,20 & 85,13 \\
\hline$R \& D$ & 0,39 & 0,49 & 0,12 & 0,57 \\
\hline \multicolumn{5}{|c|}{$\begin{array}{l}\text { Table } 1 . \\
\text { Summary of Performance and Predictor } \\
\text { Variables in } 1997 \text { and } 2002 \\
31 \text { December 1997, } 205.000 \mathrm{TL} \sim 1 \$ \\
\text { 31 December 2002, } 1.630 .000 \mathrm{TL} \sim 1 \$\end{array}$} \\
\hline
\end{tabular}

After removing outliers, the normality of the variables were tested by Shapiro-Wilk, Kolmogorov-Smirnov, Skewness and Kurtosis tests. Tests failed to find a $5 \%$ level of significance among the variables except for growth and leverage. Transformations helped the variables to pass the tests. Since there is no great difference in the results of canonical correlations between the original and transformed variables, the 
original variables were preferred in the interpretation.

Multicollinearity becomes a problem when the variance inflation factor is greater than 10 , the condition index is more than 100, or tolerance is less than 0,10 . All the tests show that multicollinearity was not a problem for either the dependent or independent variables for both terms.

\begin{tabular}{|c|c|c|c|c|c|c|c|c|}
\hline \multicolumn{5}{|c|}{1997} & \multicolumn{4}{|c|}{2002} \\
\hline & 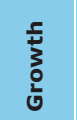 & $\begin{array}{l}0 \\
0 \\
0 \\
0 \\
2\end{array}$ & $\begin{array}{l}\text { ț } \\
\text { to } \\
0\end{array}$ & $\frac{3}{3}$ & 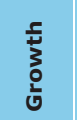 & 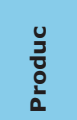 & $\begin{array}{l}\frac{t}{6} \\
\frac{0}{2}\end{array}$ & $\frac{3}{2}$ \\
\hline$R \& D$ & -0.15 & 0.06 & 0.03 & 0.03 & 0.02 & 0.08 & -0.08 & -0.03 \\
\hline Curr.Rat & 0.04 & 0.04 & $0.50 *$ & 0.06 & 0.01 & $0.46 *$ & $0.36 *$ & -0.13 \\
\hline Inv.Turn & 0.13 & $0.20 * *$ & 0.10 & 0.15 & -0.05 & 0.13 & 0.16 & -0.02 \\
\hline Leverage & -0.14 & $-0.27 *$ & $-0.62 *$ & 0.05 & -0.06 & -0.52 & $-0.75^{*}$ & $0.31 *$ \\
\hline Cashflw & 0.17 & $0.44 *$ & $0.87^{*}$ & $0.30 *$ & 0.02 & $0.54 *$ & 0.15 & -0.09 \\
\hline Size. & 0.05 & $0.42 *$ & $0.30 *$ & 0.00 & 0.09 & $0.41 *$ & $0.41 *$ & -0.02 \\
\hline MacEqp & 0.04 & $0.49 *$ & $0.27 *$ & 0.00 & 0.08 & $0.29 *$ & 0.05 & -0.01 \\
\hline $\begin{array}{l}\text { Table } 2 . \\
\text { PearsonCc } \\
\text { *significant } \\
* * \text { significa }\end{array}$ & $\begin{array}{l}\text { lati } \\
<0,\end{array}$ & $\begin{array}{l}\text { ns Bety } \\
1 \\
105\end{array}$ & D & forr & 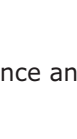 & $\mathrm{Dr}$ & the & la \\
\hline
\end{tabular}

Table 2 gives the results of the Pearson Correlation Coefficients. According to the table in 1997, there is no correlation between growth and any other variable in the analysis at a $5 \%$ level of significance. There is a highly significant positive correlation between productivity and cash flow, size, mac\&eqp and inventory turnover. The correlation is highly significant and negative between productivity and leverage. Profitability has highly significant positive correlations with cash flow, mac\&eqp, current ratio, and firm size and a negative correlation with leverage. MV/BV has a positive correlation with cash flow. The table in 2002 shows that there is no correlation between growth and any other variable at a 5\% level of significance. Highly significant correlations exist between productivity and cash flow, leverage, current ratio, size and mac\&eqp. The correlation between productivity and leverage is negative, while other correlations are positive. There is a highly significant negative corelation between profitability and leverage. Highly significant positive correlations are obtained between profitability, firm size and current ratio. There is a positive correlation between MV/BV and leverage.

\begin{tabular}{|c|c|c|c|c|c|c|c|}
\hline 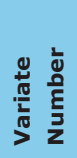 & 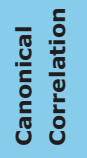 & 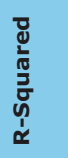 & $\sum_{\text {L }}^{\frac{0}{2}}$ & $\begin{array}{l}\frac{U}{\Delta} \\
\underline{\Sigma} \\
\bar{z}\end{array}$ & 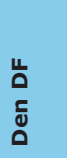 & $\begin{array}{l}\overline{0} \\
\text { ฮ } \\
00 \\
0 \\
\frac{1}{2}\end{array}$ & 隺 \\
\hline \multicolumn{3}{|c|}{1997} & & & & & \\
\hline 1 & 0.89 & 0.79 & 9.90 & 28 & 333 & $1 \times 10^{-6}$ & 0.11 \\
\hline 2 & 0.57 & 0.32 & 3.61 & 18 & 264 & $2 \times 10^{-6}$ & 0.54 \\
\hline 3 & 0.41 & 0.17 & 2.36 & 10 & 188 & 0.01 & 0.79 \\
\hline 4 & 0.23 & 0.05 & 1.34 & 4 & 95 & 0.26 & 0.95 \\
\hline \multicolumn{3}{|c|}{2002} & & & & & \\
\hline 1 & 0.73 & 0.53 & 2.44 & 28 & 207 & $1.9 \times 10^{-4}$ & 0.36 \\
\hline 2 & 0.41 & 0.17 & 0.92 & 18 & 165 & 0.56 & 0.76 \\
\hline 3 & 0.28 & 0.08 & 0.51 & 10 & 188 & 0.88 & 0.92 \\
\hline 4 & 0.05 & 0.00 & 0.04 & 4 & 60 & 0.99 & 0.99 \\
\hline
\end{tabular}

\section{Table 3.}

Canonical Corelations and Significance Levels Between

Performance and Predictor Variables in 1997 and 2002

Table 3 displays canonical correlations and their significance levels between performance variables and the predictor variables. The first canonical variates reflect the best situation in which the independent set explains the most variation in the dependent set and vice versa. Therefore, researchers generally prefer to interpret the first canonical variates. The first canonical correlations are very high and highly significant in both $1997(R=0,89, p=10-6)$ and in $2002\left(R=0,73, p=1,92 \times 10^{-4}\right)$.

Canonical coefficients, canonical loadings or canonical cross loadings are interpreted to determine the relations between dependent and independent variables. Since canonical coefficients can be misleading when multicollinearity appears in one of the sets, generally, loadings or cross loadings are prefered (Table 4). In this table, the most important canonical loadings and cross loadings are shown. According to the table, the canonical variate of the dependent set is a linear combination of the variables; growth, productivity, profitability and MV/BV and all the variables are positively correlated with the first canonical variate in 1997. Profitability, which has the highest correlation with the first canonical variate $(R=0,99)$, is the most important variable. Productivity $(R=0,58), M V / B V(R=0,33)$ has significant loadings to the canonical variate but growth $(R=0,19)$ does not. Aside from leverage, the other variables in the predictor set have positive loadings to their first canonical variate. The most important variable in this set is 
cash flow $(R=0,98)$, followed by leverage $(R=-0,67)$, current ratio $(R=0,52)$, size $(R=0,37)$, and mac\&eqp $(R=0,36)$. Inventory turnover $(R=0,14)$ and $R \& D(R=0,04)$ have no significant loadings to their canonical variate. The variables that have positive (or negative) correlations with their canonical variate have positive correlations with each other, while the variables that have corelations in opposite directions have negative correlations with each other. Thus, leverage has negative correlations with performance variables and the other variables in the predictor set have positive correlations with performance variables. According to the table, in 2002, when the first canonical loadings were interpreted, the most important variables in the set of predictor variables are leverage $(R=-0,82)$, cash flow $(R=0,82)$, current ratio $(R=0,66)$ and firm size $(R=0,54)$. Mac\&Eqp $(R=0,23)$, inventory turnover $(R=0,11)$ and $R \& D(R=0,05)$ have no significant loadings to their canonical variate. The most important variables in the set of performance variables highly loading to their canonical variate are profitability $(R=0,88)$ and productivity $(R=0,84)$. The loadings of MV/BV $(R=0,28)$ and growth $(R=0,22)$ are not highly significant. Profitability and productivity have negative correlations with leverage and positive correlations with cash flow and current ratio.

When the results of 1997 and 2002 analysis are compared, for both terms profitability and productivity were important

\begin{tabular}{|c|c|c|c|c|}
\hline & \multicolumn{2}{|c|}{1997} & \multicolumn{2}{|c|}{2002} \\
\hline & Loadings & $\begin{array}{c}\text { Cross } \\
\text { Loadings }\end{array}$ & Loadings & $\begin{array}{c}\text { Cross } \\
\text { Loadings }\end{array}$ \\
\hline & V1 & U1 & V1 & U1 \\
\hline Growth & 0.19 & 0.17 & 0.22 & 0.16 \\
\hline Productivity & 0.58 & 0.52 & -0.84 & -0.61 \\
\hline Profitability & 0.99 & 0.88 & -0.88 & -0.64 \\
\hline \multirow[t]{2}{*}{ MV/BV } & 0.33 & 0.30 & 0.28 & 0.20 \\
\hline & U1 & V1 & U1 & V1 \\
\hline$R \& D$ & 0.04 & 0.04 & -0.06 & -0.04 \\
\hline Curr.Ratio & 0.52 & 0.46 & -0.66 & -0.48 \\
\hline Invt.Turn & 0.14 & 0.12 & -0.11 & -0.08 \\
\hline Leverage & -0.67 & -0.60 & 0.82 & 0.60 \\
\hline Cash Flow & 0.98 & 0.87 & -0.82 & -0.60 \\
\hline Size & 0.37 & 0.33 & -0.54 & -0.39 \\
\hline Mac \& Eqp. & 0.36 & 0.32 & -0.23 & -0.17 \\
\hline
\end{tabular}

Table 4.

Canonical Loadings and Cross Loadings in 1997 and 2002 variables in measuring business performance. Although the contribution of MV/BV to its canonical variate decreased in 2002, the contribution of firm size and current ratio to their canonical variate increased. Growth was not an important performance variable for either term. While profitability was a more highly significant variable than other performance variables set in 1997, productivity was as significant as profitability in 2002. The variables in the predictor set that most affect business performance in both terms were cash flow, leverage, current ratio, and firm size. While cash flow was the most significant variable in the predictor set in 1997, leverege was as significant as cash flow in 2002. Mac\&Eqp was one of the important variables in 1997, but it was less important in 2002. R\&D and inventory turnover ratio were not significant in either term.

\section{Discussion}

The results of the study show that business performance can only be explained by profitability in stable times and profitability and productivity in unstable times. Profitability is a measurement of the sales performance of a firm. Cash flow ratio, the most important variable in the set of predictor variables, revealed its importance for decision makers. Cash flow is the ability of the company's cash reserves to cover a company's debts. In the long term, the ability to fulfill these responsibilies depends on profitability and debt. This ability allows for survival in unusual times. Cash reserves are also important providing raw materials and equipment in convenient conditions, and to utilize cash discounts for suitable investment opportunities.

Leverage ratio shows the extent to which debt is used in financing the company's total assets. An increase in this ratio means that the debt and the risk level of the company have increased. This causes a high interest rate risk in receiving credits. It is assumed that $50 \%$ of leverage rates are generally normal (Bolak 1998). A firm with a high earnings rate would maintain a relatively lower debt ratio because of its ability to finance itself from internally generated funds. Therefore, a negative correlation arises between debt ratio and profitability.

The value of current ratio shows the ability of the company's total current assets to cover its short term obligations. A high current ratio is beneficial for companies paying short term debts, but very high values indicate that the company has idle funds which are not being used productively. Gen- 
erally, a current ratio of 2 is assumed to be sufficient (Helfert, 1977). In developing countries, because banks prefer to give short term debts, a current ratio of 1.5 is considered acceptable. The mean of current ratios in this study were 1.78 and 1.61 in 1997 and 2002, respectively. This ratio is positively related to business performance. While current ratio has significant correlation only with profitability in 1997, it had significant correlation with both profitability and productivity in 2002.

This study determined that there was a positive correlation between profitability and firm size, and a positive correlation between profitability and mac\&eqp. In competitive areas large firms have more advantages than small firms. Because they have large market shares, they earn more. Large firms can work without high competition in areas where high equity is necessary; this provides more profitability. Large firms are more innovative; spend more on technical innovation (Co, Chew, 1997) and more professionals. Technology investments reduce costs, increasing profitability. In addition, growth in sales decreases unit costs, increasing profitability.

There are contradicting publications in literature concerning the relation of profitability to firm size. While Hall and Weiss (1967), Schmalensee (1989), Lirely (2000), Fink and Koller (2002) mention the positive relation of firm size to profitability, Osborn (1970), Elliot (1972), Toy (1974), Dhawan (2001), claim a negative relation. In Kaen and Baumann's (2003) study, for nearly half of the manufacturing firms examined, profitability increases declined as firms became larger. For most of the remaning manufacturing firms, no relation existed between size and profitability. They also found that profitability is negatively correlated with the number of employees for firms of a given size measured in terms of total assets and sales.

There was a positive correlation between productivity and firm size, mac\&eqp, cash flow and inventory turnover ratio, and a negative correlation between productivity and leverage ratio. Technology investments provided more products with less manpower. Large firms spent more on mac\&eqp. In the manufacturing industry, technology and innovation investments improved productivity in services and operations. In this study, no correlation was found between R\&D and profitability, R\&D and productivity. This was an unexpected result, because innovation is the main strength of companies in competative areas and R\&D reflects this strength. The studies that were done in this area show that R\&D expenses have a positive impact on business perfor- mance. Co and Chew (1997) determined that firms with above- average sales growth had above-average R\&D intensity and vice versa. Blundell, et. al., (1995) determined by using the data between 1972 and 1982 that there was a positive correlation between market share and R\&D expenditures in the British manufacturing industry. The same correlation was confirmed by Hall and Vopel (1997) by using the data between 1987 and 1991 for American manufacturing firms. In our study, 63 of 103 firms in 1997 and 61 of 68 firms in 2002 had no R\&D investments. This explains the absence of any correlation between R\&D and firm performance. R\&D investments are not profitable in the short term. It is a long term process. Rapid improvements in information and technology in the modern age requires permanent investment in information and technology. Due to the insufficient resources and lack of communication between universities and industry, an R\&D tradition could not be established in Turkey (Oktay, 1998).

From the relations between productivity and leverage, firm size, mac\&eqp., it is possible to draw the conclusion that because large firms are found to be less risky, they can receive credit with lower interest rates, and that because small firms can only obtain credit with high interest rates, their production costs become excessive and their productivity decreases. The existing literature on the positive relationship between productivity and leverage asserts that increased debt can lead to an increased managerial effort in operating the firm by additional investment in tangible assets, thus increasing productivity (Anderson, Prezas, 1999). Also, firms that experience the disciplinary effects of debt will manage their tangible assets more efficiently and will have more productive workers (Winn, 1997). Other factors that have effects on productivity include the education, skill and capacity of workers, and openness to new investments (Haris, 1999). Fortine and Helpman (2004), Brynjolfsson and Hitt (2000) determined the direct impact of technology investments on productivity and Bernstein (1998) determined the impact of the quality of workers, R\&D, and firm size on productivity.

In companies, money flows from cash to inventory and long term assets, then returns to cash through the amortisation of long term assets and the sale of inventory. Inventory turnover ratio analyzes how many times the company's inventories have been sold in a year. A high value of this ratio indicates the profitability of the company. Inventories are low liquidity entries in assets, therefore high inventory turnover ratio is positive. Low inventory turnover ratio 
causes the cash flow to slow down, increasing the need of net working capital. Because an increase in inventory turnover ratio decreases inventory costs, it increases cash flows, profitabilities, and productivities. Hitt, et. al., (2002) determine the positive effects of technology investments on inventory turnover. In our study, while inventory turnover had a correlation with productivity in 1997 at a $5 \%$ level of significance, it had no significant loading to overall business performance.

Market value/book value is the proportion of the price of a share to the shareholders' equity per share. The ratio is a good explanatory variable to measure share performance (Gagne, Reddy, 1999). It is possible to see high MV/BV depending on a feeling of confidence for a company, but a ratio over the average shows that the price of share is expensive, while a ratio under the average shows that the share is cheap. Sector (Ray, Tsay, 2000) interest rates and expectations are effective factors in determining the market value of a company (Stock, 1981). Chan et. al., (1992), Fama and French (1992) stated that MV/BV is effective in expressing expected income. A firm's owning a high value of MV/BV indicates the expected income of shares. Fama, French (1992) Morck, et. al., (1998) and McConnell and Servaes (1990) determined that this ratio is affected by income. In this study a high correlation was found between MV/BV and cash flow in stable times and MV/BV and leverage in unstable times. There was no significant correlation between MV/BV and firm size in this study as cited by Loughran (Trecartin, 2000). Because smaller firms are riskier than larger firms and because of the relation between risk and revenue, smaller firms may be more profitable than larger firms. The amount of dividents paid to shareholders from net profit may be more in smaller firms. This could be the reason for the lack of a relation between share performance and firm size.

No significant relation was found between value added growth rate and any predictor variable. Of the firms, 46 had negative growth and 57 of the firms had positive growth rates in the sample from 1997. When this sample was divided into two groups, firms with positive growth rates and firms with negative growth rates, it was seen that highgrowth firms have higher profitability, productivity, MV/BV, cash flow, mac\&eqp, and current ratio than the rest of the firms. However, such firms have higher leverage than lowgrowth firms. This result does not appear in the sample of 2002, an economically unstable period. Barney (1991) and Wernefelt (1984) determined that qualitative manpower, experience, competition, instutional substructure, and management are the factors of growth. Griliches (1994) ascertained that the basic factors of growth are technology and R\&D investments, which provide improvement in productivity, and the development of new products and new processes. Long term value added growth rate's continuity depends on the improvement of new technologies. Since R\&D investments are poor or non-existent in the Turkish manufacturing industry, the effects of $R \& D$ on growth could not be perceived by the analysis.

\section{Conclusion}

Performance measurement is crucial for companies. Companies must measure their performance multidimentionally. Profitability, productivity, stock returns and growth are the common targets of companies. These indicators can be used to measure business performance. Our study shows that, among these criteria, the most important ones are profitability and productivity for both economicallly stable and unstable times. There are many factors that can affect the performance of organizations, such as cash flow, debts, firm size, quality, innovation, R\&D, corporate culture, etc. Among the factors, the most effective ones investigated in this study were cash flow, leverage, current ratio, firm size and machinery and equipment. However, productivity is important as well when the economy is stable, and profitability almost determines business performance. But when the economy is unstable, productivity is as important a criterion as profitability. Similarly, cash flow, leverage, current ratio, size and machinary and equipment are critical factors in improving business performance. While cash flow is highly important when the economy is stable, leverage is as important as cash flow when the economy is unstable. Even though the effect of firm size and current ratio increased in unstable times, the effect of machinery and equipment decreased. The results of the study indicate that business performance has a positive correlation with cash flow ratio, current ratio, firm size and machinery and equipment, and has a negative correlation with leverage. Although it was not in the results of the study, business literature emphasizes that R\&D investments are urgent for long term success.

\section{Limitations of the research:}

More non-financial indicators should be employed in the analysis. 
More predictor indicators should be be included in the analysis. For instance, sales returns or average defective ratio, which measure production quality; absenteeisim, number of employee-employer disagreements or number of accidents, which measure quality of work conditions; experience of top mangers, maturity, qualified workers for growth, salaries of employees or contributions to social associations, which measure the social aims of firms.

In this study, data were collected from Turkey's top 1000 major industrial enterprises, to the exclusion of relatively small enterprises.

\section{References}

Akal, Zuhal, 1994, Total Performance, Productivity, Profitability and Cost Comparison Between Manufacturing Public Business, (In Turkish), National Productivity Centre Publications, Ankara, pp.1

Akal, Zuhal, 1996, Performance Measurement and Control in Business, (In Turkish), National Productivity Centre Publications, Ankara, pp.1

Amaratunga, Dilanthi, David Baldry, Marjan Sarshar, 2000, Assesment of facilities management performance- what next? Facilities, Vol.18, Number 1/2, pp. 66-75

Anderson, M. H., A. Prezas, 1999, Intangible Investment, Dept Financing, and Managerial Incentives, Journal of Economics and Business, 51, pp. 3-19

Barney, J.B. 1991, Firm Resources and Sustained Competitive Advantage, Journal of Management, 17, pp. 99-120,

Bernstein, Jeffrey I., 1998, Inter-Industry and U.S. R\&D Spillovers, Canadian Industrial Production and Productivity Growth. Industry Canada, Working Paper No. 19, http://strategis.ic.gc.ca/epic/internet/ineas-aes.nsf/ en/ra01581e.html, 26.07.2004

Blundell, R., R. Griffth, J. V Reenen, 1995, Market Share, Market Value and Innovation in a Panel of British Manufacturing Firms, Review of Economic Studies, 66, Issue 3, pp. 529-554

Bolak, M., 1998, Business Finance (In Turkish), Birsen Yayınevi, İstanbul, pp.31

Brigham, Eugene F., Michael C. Ehrhardt, 2002, Financial Management, Thomson Learning, 10th Ed. pp.10

Brynjolfsson, E., L. Hitt, 2000, Beyond Computation; Information Technology, Organizational Transformation and Business Performance, Journal of Economic Perspectives 14 , Vol. 4, pp. 23-48

Chan, Luis K. C., Yasushi Hamao ve Josef Lakonishok, 1992, Fundamentals and Stock Returns in Japan, The Journal of Finance, pp. 1739-1764.

Chin, Kwai-Sang, Kit-Fai Pun, 2003, Development of Knowledge-based Self-assessment System for Measuring Organizational Performance, Expert Systems with Applications Vol. 24, Issue 4, pp. 443-4554.

Co, H. C., K. S. Chew, 1997, Performance and R\&D expenditures in American and Japanese Manufacturing Firms, Int. J. Prod. Res., vol.35, No.12, pp.3333-3348

Dhawan, R., 2001, Firm Size and Productivity Differential: Theory and Evidence from a Panel of US Firms, Journal of Economic Behavior and Organization 44, pp. 269- 


\section{3}

Elliott, J.W., 1972, Control, Size, Growth and Financial Performance in the Firm, The Journal of Financial and Quantitative Analysis, Vol. 7, Issue 1, pp. 1309-1320

Fama, Eugene F., K.R. French, 1992, The Cross-Section of Expected Stock Returns, The Journal of Finance, 47, pp. 427-465

Fink, Gerhard, Wolfgang Koller, 2002, Did Accession to the EU Affect Small and Large R\&D Firms Differently? The Case of the Austrian Retail and Wholesale Sector, European Integration online Papers (EIOP) Vol. 6 No: 9, http://eiop.or.at/eiop/texte/2002-009a.htm

Fortin, P., E. Helpman, 2004, http://www.ssc.uwo.ca/economics/undergraduate/400E-001/rkim.pdf, (accessed 02.08.2004)

Gagne, Margaret L., 1999, Venkateshwar K. R. Predicting the Performance of Equity Mutual Funds, Journal of Accounting and Finance Research, V. 6, No.2, Spring, pp. 53-64

Griliches Z., 1994, Explanations of Productivity Growth: Is the glass half, American Economic Review, 84 (1), pp. $1-25$

Günçavdı, Öner, Haluk Levent, Burç Ülengin, 1999, Factors That Determine The Financial Structures of Istanbul Stock Exchange Traded Companies, (In Turkish) Banks Association of Turkey Publications, No: 209, pp.42

Hair, Anderson, Tatham, Black, 1998, Multivariate Data Analysis, Prentice Hall, pp. 443.

Hall, M., L. Weiss, 1967, Firm Size and Profitability, The Review of Economics and Statistics 49, vol 3, pp.319-331

Hall, Bronwyn H., Katrin Vopel, 1997, Innovation, Market Share, and Market Value, http://elsa.berkeley.edu/users/ bhhall/papers/HallVopel97.pdf 28.07.2004

Harris, Richard G., 1999, Determinants of Canadian Productivity Growth; Issues and Prospects, Industry Canada, Discussion Paper No. 8, http://strategis.ic.gc.ca/epic/ internet/ineas-aes.nsf/en/ra01736e.html

Hitt, Larin M., D. J. Wu, Xiaoge Zhou, 2002, Investment in Enterprise Resource Planning: Business Impact and Productivity Measures, Journal of Management Information Systems, vol. 19, No. 1, pp. 71-98

Helfert, Erich A., 1977, Techniques of Financial Analysis: A Modern Approach, IRWIN Professional Publishing, 9th ed., pp.99

Istanbul Stock Exchange, Year Books of Companies, 1998, ISE Publications, www.ise.org (accessed june, july, 2002)
Istanbul Chamber of Industry (ICI), Sept. 1997, Nov. 1997, Sept. 1998, Oct. 1998, Sept. 2002, Sept. 2003, Journals of Istanbul Chambers of Industry, (Turkish) ICI Publications, İstanbul ,

Jacobson, Robert, 1990, Unobservable Effects and Business Performance, Marketing Science, V.9, Issue 1, pp. 7485

Johnson, Richard A., Dean W. Wichern, 2002, Applied Multivariate Statistical Analysis, Prentice Hall, pp.543.

Kaen, Fred R., H. Baumman, 2003, http://www.unh.edu/ wsbe/faculty/frk/size_profit.doc (accessed 01.05.2007)

Kald, Magnus, Fredrik Nilsson, 2000, Performance Measurement at Nordic Companies, European Management Journal, 18, No.1, pp.113-127

Kaplan, Robert S. and Norton, David P., 1996, Using the Balanced Scorecard as a Strategic Management System, Harvard Business Review. (January-February) pp. 7585

La Porta, Rafael, Florancio Lopez-De-Silanes, 1999, The Benefits of Privatization: Evidence From Mexico,The Quarterly Journal of Economics, v.114, n.4, pp. 11931242

Levine, M. S.,1977, Canonical Analysis and Factor Comparison, Sage Publications, pp.6

Lirely, Roger L., Robert B. Weker, Philip L. Little, 2000, An Evaluation of the effect of the 1986 tax Reform ACT on Risk Adjusted Measures of Corporate Tax Equity, Accounting and Financial Studies Journal, Vol. 4, No: 1

Luo, Yadong, Seung Ho Park, 2001, Strategic Alignment and Performance of Market-Seeking Mncs in China, Strategic Management Journal 22, pp. 141-155

McConnell, J., H. Servaes, 1990, Additional Evidence on Equity Ownership and Corporate Value, Journal of Financial Economics 27, pp. 595-612.

Morck, R.., A. Shleifer, R. W. Vishny, 1988, Management Ownership and Market Valuation, Journal of Financial Economics, 20, pp. 293-315.

Neely, A., Gregoryy M., Platts K., 1995, Measuring Performance System Design: A literature Review and Research Agenda. International Journal of Operations and Production Management, 15 (4), pp.80-116

Oktay, Müjde, 1998, Some Determinations about R\&D Situations in Turkey From the view of R\&D expended Small and Medium Enterprises, (In Turkish), ICI Publications, No: 1998-8

Opler, T., S. Titman, Financial Distress and Corporate Performance, Journal of Finance, XLIX (3), july 1994, pp. 1015-1040 
Osborn, R.C., 1970, Concentration and Profitability of Small Manufacturing Corporations, Quarterly Review of Economics and Business 10, pp. 15-26

Ray, Bonnie K., Ruey S. Tsay, 2000, Long Range Dependence in Daily Stock Volatilities, Journal of Business \& Economic Statistics, Vol 18, No. 2, pp. 254-262

Schmalenssee, R., 1989, Intra- Industry Profitability Differences in US Manufacturing: 1953-1983, Journal of Industrial Economics 37, pp. 337-357

Shaker A. Zahra, Jeffrey G. Covin, 1993, Business Strategy, Technology Policy and Firm Performance, Strategic Mangement Journal, Volume 14, Issue 6, pp. 451- 478

Shaker, A. Zahra, Jeffrey G. Covin, 1995, Contextual Influences on the Corporate Entrepreneurship-Peformance Relationship: A Longitudinal Analysis, Journal of Business Venturing 10, pp. 43-58

Stock, Duane, 1981, A Canonical Correlation Analysis of the Moments of Bond Portfolio Return Distributions, Review of Business and Economic Research, V. 17, No. 1, pp. 64-71

Timo Salmi, Ilkka Virtanen, Paavo Yli-Olli, 1997, The Generalized Association Between Financial Statements and Security Charecteristics, Scand. J. Mgmt, Vol. 13, No.2, pp.121-136

Toy, Norman, Arthur Stonehill, Lee Remmers, Richard Wright, Theo Beekhuisen, 1974, The Journal of Financial and Quantitative Analysis, volume 9, Issue 5, Proceedings, pp. 875-886

Trecartin, Ralph R. Jr, 2000, The reliability of the book-tomarket ratio as a risk proxy, Financial Services Review 9, pp. 361-373

Wernefelt, B., 1984, A resource based view of the firm, Strategic Management Journal, 5, pp. 171-180,

Winn, J., 1997, Asset Productivity Turnaround: The Growth I Efficiency Challenge, The Journal of Management Studies, 34 (4), pp. 585-600

erim Report IR-02-068/October. Laxenburg: IIASA. Pp. 5963.

Hamilton, C.B. and A.L. Winters. 1992. Opening up International Trade for Eastern Europe. Economic Policy, April: 78-115.

Havlik, P. 2000. Trade and Cost Competitiveness in the Czech Republic, Hungary, Poland and Slovenia. World Bank Technical Paper No. 482 (November). Washington, D.C.: World Bank.

Havlik, P., M. Landesmann and R. Stehrer, R. 2001. Competitiveness of CEE Industries: Evidence from foreign Trade Specialization and Quality Indicators. WIIW
Research Reports, No. 278 (July). Vienna: The Vienna Institute for International Economic Studies.

Havrylyshyn and Al-Atrash. 1998. Opening Up and Geographic Diversification of Trade in Transition Economies. IMF Working Paper, WP/98/22. Washington, D.C.: International Monetary Fund, European II and Policy Development and Review Departments. 